\title{
De-colonizing water. Dispossession, water insecurity, and Indigenous claims for resources, authority, and territory
}

\author{
Juan Pablo Hidalgo ${ }^{1,2} \cdot$ Rutgerd Boelens $^{1,2,3,4}$. \\ Jeroen $\operatorname{Vos}^{3}$
}

Received: 19 February 2016/Accepted: 1 June 2016/Published online: 20 January 2017

(C) The Author(s) 2017. This article is published with open access at Springerlink.com

\begin{abstract}
Set against the background of struggles for territory, livelihood, and dignified existence in Latin America's neoliberal conjuncture, this paper examines contemporary Andean Indigenous claims for water access and control rights based on historical arguments. In the case of the Acequia Tabacundo irrigation system in the north-Ecuadorian Highlands, the rights claims deployed in peasant-Indigenous struggles are cultural and social hybrids. They are rooted in Indigenous history, but also spawned by centuries of interaction with and defense against colonial and post-colonial frames imposed by the Spanish Empire, modern Ecuadorian State structures and influences of transnational capital. Through these conflicts over Indigenous water rights, authority, and identity, this article illustrates and examines the role of Indigenous accounts of their water histories, striving to reclaim, and govern their water territories in times of booming export-flower water extraction.
\end{abstract}

Keywords Water governance - Water rights - Indigenous communities · Flower business · Extractive industries · Ecuador

Rutgerd Boelens

rutgerd.boelens@wur.nl

Juan Pablo Hidalgo

J.P.HidalgoBastidas@cedla.nl

Jeroen Vos

jeroen.vos@wur.nl

1 CEDLA Centre for Latin American Research and Documentation, University of Amsterdam, Roetersstraat 33, 1018 WB Amsterdam, The Netherlands

2 Department of Geography, Planning and International Development Studies, University of Amsterdam, P.O. Box 15629, 1001 NC Amsterdam, The Netherlands

3 Department Environmental Sciences, Wageningen University, P.O. Box 47, 6700 AA Wageningen, The Netherlands

4 Department Social Sciences, Pontificia Universidad Católica del Perú, Av. Universitaria 1801, San Miguel, Lima, Peru 


\section{Introduction}

In Latin America, as in other regions of the world, transnational trade in agricultural produce is booming. Exports of fresh vegetables, fruits, and flowers have doubled in the past decade; international biofuel business is expectant (Baud et al. 2011; Bebbington 2009; Yacoub et al. 2015). Permissive governmental policies for expanding water-intensive crops have helped large agricultural companies accumulate water rights. These expansion processes compete for water and land with small local-Indigenous farmers, degenerate local ecosystems, undermine local food security, and profoundly alter existing modes of production and income distribution (Berry and Mollard 2010; Boelens and Vos 2012; Lynch 2012; cf. Finn and Jackson 2011; Jackson and Palmer 2015).

Private companies' accumulation of both land and water-in a context of global neoliberal policies that increasingly impact local communities and Indigenous territories, more and more deeply-once again shows how powerful regions and stakeholders assure their own supply of foods and high-value products, literally draining distant localities and economically less powerful peoples (Harris and Roa-García 2013; Perreault 2014; Vos and Hinojosa 2016). This legal, extralegal or illegal theft of rural communities' and Indigenous peoples' land and above all their water sources curbs their own local territorial control (Duarte-Abadía and Boelens 2016; Hendriks 2010; Roa-García 2014; Rodriguez de Francisco et al. 2013).

As we show in this paper, for most Indigenous families and communities, water security is determined not just by absolute availabilities of water in their territories; most of all it is a function of historical and contemporary distribution patterns of resources and services (quantities and qualities), in a context of threats and encroachment practices (Babidge 2015; Hoogesteger and Verzijl 2015; Hoogesteger et al. 2016; Saldías et al. 2012; Zoomers 2010). This means that water security for one group of actors commonly entails water insecurity for others. Water security in this sense is both a historical reflection and an important force constituting prevailing social power relations. With today's increasing pressure on water resources, water insecurity is therefore a socio-political relationship that is felt hardest by socio-economically and politically less powerful societal groups (Boelens and Seemann 2014; Zwarteveen and Boelens 2014; Seemann 2016). A clear illustration is the case of peasant and Indigenous communities in the Andean highlands. Throughout history, their water security, based on generations of making investments in building and maintaining infrastructure and embedded in collective institutions, has been constantly under threat of colonial and neo-colonial encroachment powers and practices (Hoogesteger and Verzij1 2015; Terhorst et al. 2013; Zimmerer 2000). And these days, the water they need for their livelihoods and food security is increasingly being seized by powerful actors, national elites, and transnational enterprises who are often supported by public policies and investments that favor re-allocations to supposedly more productive or efficient uses (Achterhuis et al. 2010; Vos and Boelens 2014).

Increasingly, water grabbing is expanding to mining, hydropower, energy, and urban water supply sectors (e.g., Duarte-Abadía et al. 2015; Hidalgo et al. 2013; Perreault 2014). The characteristics of threats to Indigenous water security vary by usage sector. For example, the mining and hydrocarbon sectors' threats to local use hinge upon environmental pollution (e.g., Bebbington et al. 2010; Hogenboom 2012; Stoltenborg and Boelens 2016). The hydropower sector often jeopardizes local water security, by drastically altering the continuity and timing of available water flows, for both human activity and stably operating ecosystems. As shown, for example, by cases analyzed by Bauer (1998) in Chile and Duarte- 
Abadía et al. (2015) in Colombia, changing rivers' flow seriously impacts the survival of fishing communities, or may keep back river water just when Indigenous farmers need it most.

This article analyzes water grabbing by the capitalist intrusion of flower exporters, threatening Indigenous communities who manage the Tabacundo Irrigation System in Ecuador's Highlands. Growing production and exports of flower products-which require (plentiful) water volume and distributive security-have major implications for water governance and dispossession (Boelens and Vos 2012; Gaybor 2011; Hidalgo 2010, 2016). Indigenous communities respond dynamically, using their historically-rooted collective action, and their political-strategic norms and identities under the current political-legal climate of multi-culturalism (Boelens 2015a, b; Seemann 2016).

Data were gathered for this article in consecutive field research periods in Tabacundo since 2009, and also based on a history of almost three decades' research into Andean irrigation and its political ecology. This research is based on participatory observation, review of historical documents and semi-structured interviews with canal users, public officials, flower company managers and local politicians. This document is part of the research program on the Tabacundo flower sector by the international Water Justice alliance (www.justiciahidrica.org) and the research program on Transnationalizing Local Water Battles (funded by NWO-WOTRO, the Netherlands Organisation for Scientific Research), which have organized debates on these issues.

The next section presents some general conceptual and empirical considerations regarding Latin American water-extractivism in neoliberal times, affecting Indigenous peoples and communities. We reviewed recent history and the present time, and the ways that affected Indigenous communities strategically respond using hybrid norms and identities. Section three analyzes water grabbing and response in Tabacundo, Ecuador. Section four presents brief reflections, discussion, and conclusion.

\section{Dispossession of Indigenous waters and the dynamics of identity politics}

Throughout Latin American history, accumulation of land and water by the powerful has significantly contributed to poverty and now continues deeply jeopardizing water and food security for those with less power and voice, while also degrading the environment (Bebbington 2009; Boelens 2015a, b). Unequal distribution of water is due not only to colonial exclusion and historical usurpation of Indigenous communities' water rights, but also to contemporary policies. Allocation and investment policies have focused on benefitting agro-export, logging and mining companies, and providing water and electricity for industries and mega-cities (e.g., Schlosberg 2004; Duarte-Abadía et al. 2015). Rising international ore prices and opening markets under neo-liberal policies have spawned evermore extractive industries. From Chile to Bolivia, from Peru to Mexico, the mining sector seriously threatens Indigenous communities' ecosystems and water security, by using and especially by polluting their water. Meanwhile, agro-exports from Argentina, Peru, Chile, Colombia, and Ecuador use ever-more water (e.g., Achterhuis et al. 2010; Romano 2012; Stoltenborg and Boelens 2016; Vos 2010).

\section{Opening Mother Earth's blood veins}

In their eager rush to liberalize and offer the necessary natural and human resources to strengthen market relations and appeal to transnational business capital, extracting water, 
both 'virtual' 1 and actual, is a key element of new Latin American agrarian policies, also in the Andean countries (Harris and Roa-García 2013; Vos and Boelens 2014). Both large-scale mining and large-scale commercial crops consume, degrade, and pollute water sources. Exporting metallic ore involves a flow of 'virtual water' from vulnerable zones toward rich foreign zones, while extraction, pollution, and degeneration of peasant-Indigenous territories affect the local population, who often get little good out of these production and international trade activities, but do suffer greatly (Boelens and Vos 2012; Vos and Hinojosa 2016).

The development models pursued by the Andean countries' 'left-wing governments' (which came to power in the period between 2006 and 2011) such as Peru, Bolivia, and Ecuador all claim respect for Mother Earth and Indigenous peoples' territories. However, while different in their ideological orientations, they all share their dependence on extractive activities for export, especially mining and hydrocarbons, but also agribusiness (Bebbington et al. 2010; Boelens et al. 2015). With a few exceptions, most of these activities are done in ancestrally Indigenous territories, both in highlands communities and in Amazonian plains or coastal valleys along the strip of desert in Peru and northern Chile. The fundamental status of extraction for export and the sizable investments this requires has earned these investments special treatment (e.g., Bebbington et al. 2010; Budds and Hinojosa 2012; Hendriks 2010; Hogenboom 2012).

In the Andean countries, large-scale investments have occupied the territory of peasantIndigenous communities, transforming their environment and resource management. This is often illegal, without the legally-established minimum share of votes by community members accepting the occupation. Plundering water sources and concentrating them under private ownership is facilitated because some Indigenous communities have no formal property title to their lands, even if they have lived there for many generations. Taking advantage of this situation, large companies have begun aggressively seizing Indigenous communities' water sources, in some cases purchasing the rights for a song, but in others using State powers and force to evict or expel the Indigenous people (Bebbington et al. 2010; Boelens and Seemann 2014).

Chile provides a dreadful example. In 1981, Chile's military junta enacted the Water Code, strongly influenced by neoliberal ideology and forcefully introduced by general Pinochet's dictatorship. Profit-seeking sectors of the economy were favored, and traditional collective economies were legally circumscribed (Bauer 2005; Prieto 2015). Contrary to Indigenous customs, water rights were separated from land rights and transformed into a tradable commodity, with private property status. To facilitate the transfer to more profitable uses such as industries, previously existing legal priorities for water allocation (to socially crucial uses such as drinking water and livelihoods) were eliminated. Indigenous water systems were largely ignored in the 1980 s, and most water rights were allocated to large landowners, agro-industries, mining and logging companies. In many cases, whole Indigenous settlements that previously had natural access to water were now given restricted, irregular access. Here, Indigenous water rights were overlaid by new market practices and the individualization of formerly collective rights and management systems has created internal disruption in many communities (Achterhuis et al. 2010; Bauer 2005; Budds 2010).

\footnotetext{
1 Water use, concentration, and pollution by extractive (mining and agro-export) industries can be seen as flows of 'virtual water' (Allan 2003). Virtual water is the water used and contaminated to make a given product. The concept was originally used by Allan to propose a market solution for water scarcity in arid countries: for example for Egypt, it was considered cheaper to import wheat than to 'produce' or 'import' the water necessary to grow its own wheat. However, flows of virtual water often originate from poor, water scarce areas (e.g., Indigenous territories), and negatively impact water availability and quality.
} 
Although Chile enacted its Indigenous Law in 1993, to protect leftover water and territorial rights, the neoliberal Water Code and mining regulations are far more powerful. Legally defending Indigenous rights and community laws against third parties is very difficult in an overall neo-liberal framework that destroys collective organization and favors individual and private rights (Achterhuis et al. 2010; Hendriks 2010). Chile's neoliberal ideology preaches that Indigenous groups must either fit into the market or count themselves out of the process of 'globalizing progress' (Boelens et al. 2009; Budds 2010). While explicitly expressed in Chilean water legislation, this same policy assumption is widely spread among other Andean country governments and overall public opinion. It is also deeply reflected in the continuing practice of capitalist water extraction in the region's Indigenous territories (Boelens et al. 2009).

\section{The historical image of Pishtaku: draining Andean communities' vital forces}

Historically, among communities in the Andean countries, land and water accumulation by the few, producing scarcity among the many, evokes the image of a vampire. So, in Todas las Sangres, the masterpiece by Peruvian novelist and anthropologist José María Arguedas (1964), this classic category of oppressors is personified by landowner Don Lucas, a bloody character who treated his Indians with savage violence. The Indigenous world associates Don Lucas with the 'nakak' or 'pishtaku', the Andean vampire. In that same book, Arguedas portrayed major political and economic changes in the Andes, in the mid1900s, with new mechanisms for the dominant classes to usurp land and water. The gamonal hacienda boss is a figure of the past, but his essence has re-emerged, both in political and economic practice and in the imagery of the pishtaku. As the hacienda owner Don Fermín, protagonist of Todas las sangres, put it, the transnational Wisther and Bozart Mining Company had come to devour not only persons but also whole towns, haciendas, and even mountains and Nature; it was the "new driver and hidden witness of change". Fermín compared these new international capitalistic consortia, "these nameless monsters" as he called them, with "phantoms" and "invisible bosses". The new globalizing power, squashing existing production relationships, was not strengthened through visible oppression but by its invisibility, the characteristic of modern capillary power (that is: power that is dispersed in society, not imposed from one dominant actor, and self-inflicted) and the invisible hand of the transnational market.

The pishtaku is the mythical Andean vampire who skins its victims and sucks their fat. Human in appearance, this big nocturnal, blond-haired, violent demon is a metaphor for outsider dominant groups and landowners who come to drain wealth and life energy from inhabitants of the Andes. Transforming power relationships in the region has also metamorphosed the pishtaku and its practices. ${ }^{2}$ Where old folk tales dealt with sorcerers and their man-eating practices, ${ }^{3}$ recent versions have them extracting fat to lubricate modern technologies, such as locomotives and weapons. ${ }^{4}$ During Peru's financial crisis in the 1980s, the fat was for central government power groups to export, to pay off the foreign debt. They also claimed that the fat was to fuel airplanes, space ships, or for plastic surgery for elites in the North (Ansión 1989). Extracting, marketing, and trafficking in this vital

\footnotetext{
2 See, e.g., Ansión (1989), Arguedas (1964), Portocarrero (1991), among others.

3 According to Guamán Poma de Ayala $(1615,251)$, pishtaku fiends “took persons' fat... did ceremonies... and spewed to the idols and cows and made them speak to their temples and demons...".

4 Nakak' (ñakaq) and pishtaku (pistaco) both refer to the same supernatural being. Pishta (Quechua): "to behead", "to skin". In Bolivia they are called karisiri (or liqichiri), (Quechua: 'fat-sucker').
} 
commodity-symbolizing the common folk's raw materials-by the Government, the Shining Path, large landowners or gringos and capitalist companies-are the core trend in tales of the phantom pishtaku. The pishtaku is an allegory, an incarnation of changing relations of exploitation, power, and domination.

So, the imagery and reality of Andean Indigenous communities, a new, trampling appearance of this parasitic monster, is the modern structure of transnational extractive industries-mining and agro-export extraction companies that 'suck the Earth's blood' to export it abroad.

\section{Indigenous water rights and recognition struggles 5}

In order to facilitate extractivism and water dispossession from Indigenous communities, throughout the centuries, colonial and post-colonial governments and elites have carefully devised the cultural politics game to impose a 'proper blue-print for behaving' on Indigenous water users (see Boelens 2015a). This entails a design for State-aligned identity (including, these days, market-based belonging), subjugating water users subtly or less subtly to official national identity and formal water culture. As Boelens (2015a, b) explains, Andean countries' recognition policies are often a 'politics of recognition' to 'correct' deviant groups, rights, and behavior. Indigenous water user groups, however, also define their own cultural-political projects, refusing to accept selfhood as a mechanical reflection of prevailing power relations. They react to, modify and strategically use the ruling symbolic order.

On the one hand, Indigenous water rights, norms, and identities are politico-strategic constructs. Indigenous organizations dynamically shop around (von Benda-Beckmann 1981) in national and other normative systems and discourses, appropriating elements that can legitimize their claims. Here, ethnicity and Andean or Indigenous identity can be considered as a political strategy in the struggle by local communities and supralocal organizations to defend their rights vis-à-vis the colonial and postcolonial State and other powerful water interest groups.

On the other hand, Andean communities show specific historical and cultural forms of collective action and resource management, embedded in specific Andean cultures with their particular normative repertoires, symbols, and livelihoods (Gelles 2010). Struggles of Indigenous and peasant water collectives in the Andean Highlands lend a deeper insight into how the 'mutual bonds of rights and obligations' and the 'sense of belonging' among water users, and among users and their water sources, is strengthened; how a common 'hydraulic property' is created and re-affirmed, and how 'water cultural identities' acquire their actual substance (see, e.g., Boelens and Vos 2014). To operate adequately, Indigenous communities and water user collectives must establish their criteria for membership and boundaries, defining their identity and exclusiveness, within the political field where they operate. Such political fields have many levels, ranging from households up to the (inter)national domain.

Therefore, though always constituting dynamic institutions, Indigenous water rights, identities, and boundaries are not only 'limitless', 'tactical', 'fluid', and 'disposable'. As Orin Starn once commented, the Andean Highlands are “... a place of synthetic, shifting identities that have grown out of the multi-layered interactions of the local, the regional, and the global since pre-Columbian times" (Starn 1994, 20); ethnicity and identity in contemporary Andean society is the outcome of intensive interaction between different classes and cultures (Boelens and Gelles 2005).

5 This section is based on Boelens et al. (2009). 
So the false, frozen, culturalist caricature must be debunked: Indigenous and other rural water control and management systems are not age-old but constantly evolving through social experimentation and cognitive synthesis by local users and leaders to suitably reproduce and regulate their water systems (e.g., Gelles 2010; Guevara-Gil 2010; Starn 1994). In this process, their normative frameworks, disciplinary practices, and conflict management are informed by a diverse range of sources and influences that can include government law, international law, rules proposed by development agents intervening in their systems, legal practices by nearby peoples or communities, dissemination of universalistic discourse (e.g., human rights, neoliberalism) or their own local innovation. For example, in Peru, following successful Indigenous identification struggles in neighboring Ecuador and Bolivia, peasant communities and supralocal organizations are increasingly claiming their Indian ancestry in order to get full coverage from the international law on Indigenous rights and the environment (Boelens et al. 2009; Guevara-Gil et al. 2010).

\section{An Ecuadorian illustration: Indigenous communities' struggles for water control amidst booming export-flower agribusiness}

In Ecuador, as in neighboring countries, limited access to water results from natural and climatic factors, but mainly from economic and political power wielded against users competing for water resources in their territory (Cremers et al. 2005; Gaybor 2011; Hidalgo 2010, 2016).

Here we present the historical problems of access to irrigation water in the Acequia Tabacundo in Ecuador's northern Andes. The flower industry-which official discourse flaunts as the epitome of economic progress, technological developments and green alternatives - is the last link in a historical chain of powerful stakeholders who, in fact, have always coveted Indigenous water (Zapatta and Mena-Vásconez 2013; Poats et al. 2007; Mena-Vásconez et al. 2016). This new modality to accumulate water uses dispossession mechanisms characteristic of countries basing their development on recommoditizing $^{6}$ their economy. This historical seizure of land and water by large national and transnational companies includes reallocation of water resources and land ownership previously owned by Indigenous communities, generating contradictions and conflicts.

\section{A history of political-economic and ethnic-cultural contradictions}

The Spanish crown significantly influenced access to and management of means of production in Cayambe and Tabacundo. Colonial forms of slavery introduced with the Conquest, such as encomiendas ${ }^{7}$ and haciendas ${ }^{8}$ imposed colonizers' culture and religion to civilize the Indigenous and take over their land and water. First, encomiendas were the

\footnotetext{
${ }^{6}$ Countries adopting the economic model of going back to heavy dependence on exports of commodities with little value-added (see e.g. Rehner et al. 2014).

7 The encomienda was introduced by the Spanish crown early in 1535. "An encomienda should be a reciprocal relationship [between colonizers and subjects]; the Indigenous would work some days a week for the encomienda masters and in return the masters must protect the Indigenous and ensure their education and conversion to Catholicism"; however, this was just to legitimize the process of enslavement and indebtedness. (Becker and Tutillo 2009, 46).

${ }^{8}$ Hacienda was a large land-holding where the Indigenous were exploited, living only to serve the hacienda master, who was either a colonizer or local creole elite. This form of landholding was predominant in the zone until the first agrarian reform in 1964.
} 


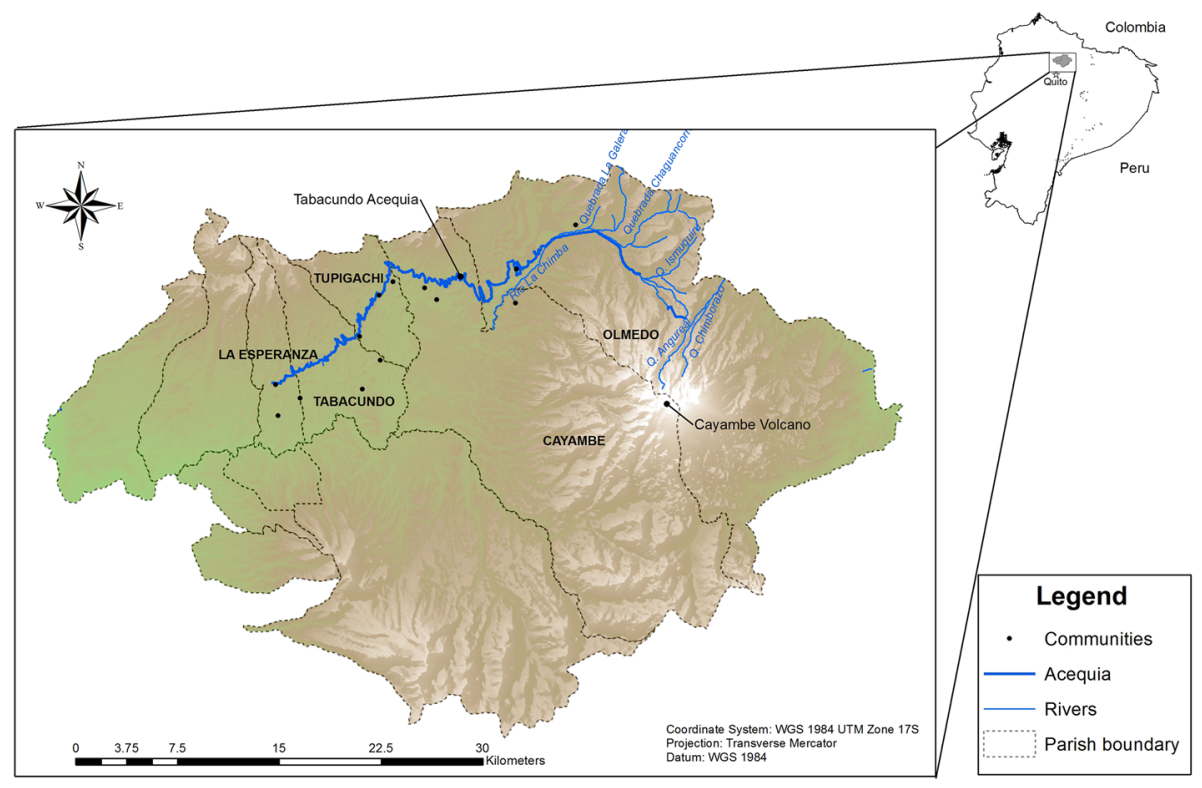

Map 1 The Acequia Tabacundo system in the northern highlands of Ecuador

basis for concentrating land and dominating the native inhabitants. Encomienda masters also imposed their own culture and identity, while concentrating and privatizing land and water and enslaving labor. From the 17th century onward, under the hacienda system, these power relationships were institutionalized. Haciendas held the best farmland in valleys, displacing Indigenous to higher zones with poor-quality soils. Many Indigenous people were property of the hacienda, while others remained 'free' at higher altitudes. The former were forced to work for the hacienda in exchange for a pittance and the 'right' to farm a small plot for their own subsistence. This system was called huasipungo. They also had to ask the hacienda master for permission to use water, fuelwood, and pasture for their animals. Only Indigenous people living in 'free communities' had some independence for water and land management, although they also worked for the haciendas at times of peak demand, such as harvest or planting (Buitrón and Salisbury 1947; Becker and Tutillo 2009; Sawers 2005). The exploitative system remained in force until the 1960 s when the first agrarian reform was implemented.

Construction of the Acequia Tabacundo irrigation system ${ }^{9}$ began in the early 20th century. In 1902, the people of Tabacundo endured a severe drought, which led the haciendas to seek water sources to ensure supply for coming years. So, a year after, an expedition to volcano Mount Cayambe found creeks running eastward to the Amazon basin (see Map 1).

That year, these water flows were awarded by the national government for Tabacundo's use. As accustomed in that time, under huasipungo regime, construction was led by local elites, bossing peasant-Indigenous labor, both 'free' and huasipungo peoples. Indigenous peoples were the ones who invested time and labor in bringing the water to Tabacundo. Although construction began straight away, there was then a prolonged pause until 1914,

9 Acequia means "canal" in Spanish. However, here the "Acequia Tabacundo" is the name of the complete Tabacundo irrigation system. 


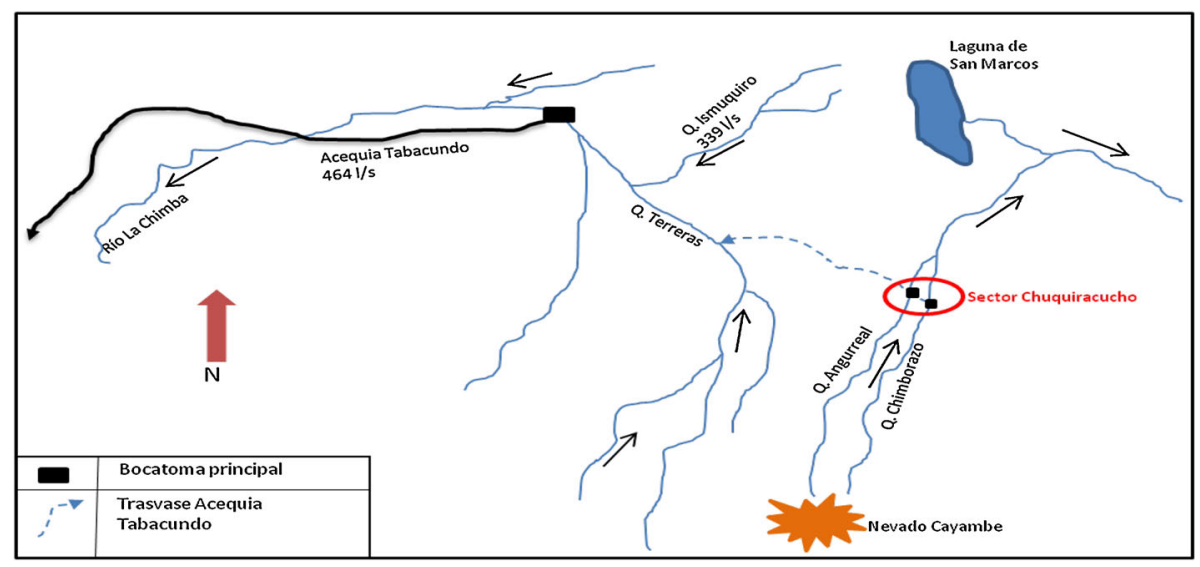

Map 2 Water sources of the Acequia Tabacundo. Source Hidalgo (2010)

when the municipality of Pedro Moncayo took over and built another $20 \mathrm{~km}$ of canal. Finally, water reached Tabacundo in 1930, after a series of minga workparties manned by nearly 4,000 Indigenous labourers each (Chontasi 1987; Poats et al. 2007). The canal is $122 \mathrm{~km}$ long overall, and from the main intake (La Chimba River), $65 \mathrm{~km}$ (see Map 2).

Agriculturally, the zone has two agrarian landscapes: One landscape is many small farms owned by Indigenous families growing crops that bolster their food and economic sovereignty. The main crops include wheat, peas, fava beans, potatoes, chocho beans, melloco, mashua, lentils, corn, pasture, and vegetables in general. The other landscape are the haciendas remaining after agrarian reform, owned by local bourgeoisie families. Although the huasipungo system was gradually abolished, starting with the first agrarian reform in 1964, only part of the large-holdings (those owned by the Church and the State, which were rented to local bourgeois families) was re-distributed, granting ownership to peasant-Indigenous families who had been enslaved. The reform had little impact on redistributing the other large-holdings, most of which were held by powerful local elites. They traditionally grew cereal grains and kept sheep on their properties.

During agrarian reform, in the 1950s and 1960s, a series of changes in national policy encouraged modernization of these large haciendas. Large properties began reconverting to high-quality dairy cattle, moving from low-productivity extensive production to high technology. In this context, unlike many other cases in Ecuador's Highlands with unending conflicts over scarce water between haciendas and Indigenous communities, the Tabacundo irrigation water was still enough for both sectors, since there were few users (as many communities were excluded from using the canal's water) and with relatively low water needs. At this time, since the system was inaugurated in 1930, the Municipality of Pedro Moncayo formally administered the Acequia.

In the mid-1980s, the zone's landscape began to change. This change affected the agrarian, economic, political, and socio-organizational structure. Flower plantations came into the zone and set up mainly in the Acequia's lower and mid-altitude zones-where large farms had operated-among other reasons because this zone is close to the highway from Tabacundo to the Quito airport. They first set up in Pedro Moncayo district and then spread to neighboring Cayambe, driven by a combination of factors. There is the market niche demanding high-quality flowers in the United States and Europe, leading foreign and Ecuadorian capital to invest in Ecuador. This is due, among other things, to Ecuador's 
comparative advantages: good climate, 'availability' of water, cheap land, optimal geographical location, cheap labor, openness to investment, good roadways, etc. Further, in those years Ecuador was consolidating neoliberal capitalist structural adjustment policies promoting this type of investments. ${ }^{10}$ Some haciendas in the region became intensive dairy farms, with improved-breed dairy cows. Moreover, temporary and permanent out-migration increased, as peasant-Indigenous farmers moved to nearby towns to sell their labor. Much of this was driven by the economic pressures of neoliberal policies, pushing Indigenous families out of their homes and communities (Korvkin and San MiguelValderrama 2007). Flower-growers found plenty of young, cheap labor (Poats et al. 2007). Especially the cattle farms converted to flower-growing. However, it was not until the early 90s when the flower sector grew significantly, multiplying exports tenfold over an eightyear period (see also Rubio 2008).

Neoliberal-capitalist policies, as in other countries of the region, have neglected the small and medium family farming sector. Ecuador has over 4,000 community irrigation systems, thanks to historical Indigenous construction, operation, and maintenance, but they have been almost totally ignored by public policies (Gaybor 2011; Hidalgo 2010). By contrast, national policies have constantly wooed transnational capital to promote the agroindustrial commodity export sector and transform hydro-social territories. Flowers for export are a 'star' of agroindustry, mainly from the Highlands. As we have mentioned, the flower sector has grown dramatically over the last 30 years. Before the sector's current crisis, in the 2001-2012 period the dollar amount of Ecuador's flower exports grew steadily by over $11 \%$ per year, positioning the country as the world's third-largest flower exporter (PROECUADOR 2013). The social fabric in the Tabacundo region changed fast because of the flower boom. Soper (2013) provides an account of the social changes and social and political struggle in Tabacundo due to the high influx of migrant workers, many women working in the flower greenhouses, changing consumption patterns and competition for water.

\section{Conflicts over water between Indigenous communities and flower-growing companies}

In this new context, the Acequia Tabacundo's problems have evolved, $50 \mathrm{~km}$ north of Quito. This rural Andean zone has highly favorable ecological conditions for agriculture. ${ }^{11}$ The community irrigation system crosses through two districts in the province of Pichincha: Cayambe and Pedro Moncayo. ${ }^{12}$ The canal uses water from the La Chimba River, which is fed by thawing from Mount Cayambe's snowcap (Map 2). The acequia receives a flow of 464 1/s, authorized by the Government.

It irrigates approximately 4,700 hectares, benefitting 49 rural-Indigenous communities totaling 2,600 users. $91 \%$ of them are small and medium peasant-Indigenous farmers, $5 \%$ are flower growers and the other $4 \%$ are cattle raisers, see Table 1 (Hidalgo 2010, 2016). Empirical evidence gathered over the last six years (2009-2015) shows how power

\footnotetext{
10 The structural adjustment driven by the World Bank and the International Monetary Fund implemented policies discouraging production by small and medium farms and encouraging modernization and agroindustrial investment. One of these policies was to exonerate flower exports from customs duties until 2001.

11 Straddling the equator, Ecuador has about $12 \mathrm{~h}$ of daylight every day, plus good-quality water and weather.

12 The Republic of Ecuador is politically and administratively divided into provinces, cantons, and parishes. Each parish can have neighborhoods, communities, and/or hamlets.
} 
Table 1 Stratification of Acequia Tabacundo users by production systems.Source Authors, field work

\begin{tabular}{lrrrrr}
\hline Production systems & \multicolumn{2}{l}{ Users } & & \multicolumn{2}{l}{ Irrigated land } \\
\cline { 2 - 3 } & Number & $\%$ & & Hectares & $\%$ \\
\hline Flower producers & 124 & 5 & 952 & 20 \\
Cattle farming & 95 & 4 & 1,348 & 29 \\
Smallholder subsistence & 2,237 & 91 & 2,396 & 51 \\
Total & 2,456 & 100 & 4,696 & 100 \\
\hline
\end{tabular}

relationships have benefitted flower growers, giving them access privileges to secure irrigation-water supply at the expense of peasant-Indigenous small farmers. ${ }^{13}$

As mentioned, access to land and progressive exploitation of the labor force who would otherwise be peasant-Indigenous farmers have been determining factors in developing the zone's flower agroindustry. The speedy growth of the flower sector has spurred land speculation, especially along the lower and mid-canal area. Investors offered as much as nine times the value to individual rural families for their land, when they were near the canal. This phenomenon resulted in (i) converting the best land from livestock and food production to flowers; (ii) land transfer from small farmers to investors; and (iii) serious threats for Indigenous community life and collective survival from commodification and individualization. Many peasant-Indigenous families who sold their land ended up working as laborers for the capitalistic flower farms. ${ }^{14}$

This irrigated land ownership transfer is clearly reflected in Table 1. Although peasantIndigenous are the majority users $(91 \%)$, they have only $51 \%$ of the land under irrigation. By contrast, $49 \%$ of irrigated land is owned by $9 \%$ (the flower and cattle sector) and, unlike Indigenous communities, has far better irrigation water coverage. They also have greater capacity to tap canal water, because agribusiness can afford to install technology (computerized drip irrigation, reservoirs). This enables them to store more water and legitimizes their discourse of priority for access to water compared to the precarious, 'inefficient' way small farmers irrigate, who have less capital to invest in technology.

In 1979 the Agricultural Development Law was enacted protecting and guaranteeing property rights for large and medium owners who "produced efficiently". This Law encouraged individual land ownership with benefits for those farmers that could demonstrate "efficiency in production". Small and medium owners also joined in this wave of getting title to their land. Large farms in the zone legally consolidated, while collective ownership rights were individualized and included in the free land market. This opened the doors for economically powerful stakeholders to purchase and monopolize land.

The Acequia Tabacundo was administered by the Municipality of Pedro Moncayo for many decades up until 2006. During that period, it was hard for small farmers to access the

\footnotetext{
${ }^{13}$ For example, many flower companies have access to a flow rate of $32 \mathrm{l} / \mathrm{s}$ for their own use, while that same volume of flow is distributed among over 80 families in the Indigenous sector. (Hidalgo 2010).

${ }^{14}$ Many peasant-Indigenous families who sold their land, especially along the lower canal, saw work for the flower farms as an opportunity, with a fixed salary that could not be lost as crops could be lost. However, working with agricultural chemicals, over 8 hours a day during peak seasons, under pressure, meant they were exploited laborers with very low salaries, with no stability in the medium term as staffing fluctuated. Further, being employed by the farms, with their income depending on their salaries, they often were forced to steal irrigation water from their own communities for the flower farms' benefit in order to keep their jobs. In conclusion, individualizing land rights/ownership and then transferring these properties from Indigenous farms to capitalist flower businesses triggered a monopolization of irrigation water rights and dispossessed Indigenous farmers form their means of production.
} 
water, which they were officially entitled to, because of the municipal policy of differentiated water rates. During municipal administration of the canal, the water turn cost differentiated rates (for 8,16 or $32 \mathrm{l} / \mathrm{s}$ ) based on the typology of production systems and flow rate.

The fees, based on $1 / 4$ of a molino $(8 \mathrm{l} / \mathrm{s})$, according to user types, are: US\$ 0.40/day for communities, US\$ 1.90 for cattle ranchers, US\$ 3.75 for small flower growers, US\$ 5.00 for middle-sized flower growers, and US\$ 10.00 for big flower companies. Thus, the big flower companies pay 25 times more per cubic meter compared to the smallholders. Essentially, although this policy claimed to benefit small and medium farmers through a cross-subsidy, in political practice it was used against them: the municipal authorities preferred flower-growing users over local communities because they paid more per unit of water. Consequently, they gave priority to providing plenty of highly secure water to flower companies. They guaranteed water for the users who paid the most.

Economic power also corrupted the distribution of water from the canal. Flower growers and small Indigenous farmers have bribed the aguateros (who operate the infrastructure and distribute water from the canal) and municipal authorities as a mechanism to obtain actual access to water. However, small farmers have not gotten the same results as the flower companies. Since aguateros are directly responsible for opening and closing distribution gates from the main canal, some flower farms have even included them on their payrolls, giving them a monthly salary for ensuring continual water supply for the greenhouses. Farmers tried to play the same game, but were obviously outspent. One small farmer said: "[...] the corruption was fierce ... for the aguatero to give you water was a whole process, first giving him a chicken, cheese, and all kinds of incentives... even so, they wouldn't give us water because they were committed to the flower companies [...]" (Indigenous small farmer from the Acequia Tabacundo). Nevertheless, a few peasantIndigenous could afford to bribe more and got water, but by paying almost 30 times more than the municipal rate. Bribery involved more than just paying for access to water; bribes were sometimes in lieu of fines for stealing water (which flower companies do on a daily basis). ${ }^{15}$

Flower farms stole water abusively by circulating at night with gangs of private guards and/or local employees from neighboring farms, who, ironically, were sometimes among the Indigenous small farmers whose land downstream was left dry. That is, they were forced to steal their own water. Individual Indigenous families could do practically nothing to stop such actions, because the armed guards threatened anyone who tried to interrupt or denounce these actions.

Because of this type of power wielded by flower growers over other users, access to the canal was also limited under municipal administration, even by municipal officials. Many plantations prohibited access to the canal when it ran through their properties. This way, flower growers were free to manipulate the distribution gates, and there was no way to check on this theft.

To round out the corrupt practices, water theft and denial of access to the acequia, flower companies have set up reservoirs, pumps, and wells. The technology they can afford completes this exclusion from access to irrigation water. Building reservoirs as big as $30,000 \mathrm{~m}^{3}$ enables them to store up water and make sure that they have water even if no one else does. Using pumps, pipes, and deep wells achieves access to water efficiently and quickly.

15 Theft was easy for flower farms alongside the canal, or with branches of the canal inside their properties. This was arranged by purchasing the best-located land around the canal route. 
This political and economic context of concentrating water for a few farms was sustained by discourse to legitimize it. Since flower plantations first came to the zone in the mid-1980s, their discourse of social and economic development claimed that flower growing is the sector earning the most foreign exchange for the zone and generating thousands of jobs; that is, improving people's quality of life. A flower manager said: "the farm has $8 \mathrm{l} / \mathrm{s}$ for 15.69 hectares and gives work supporting 180 families directly, while using water more efficiently than small farms. They should use more efficient irrigation methods, almost like the flower farms...this farm brings USD 3 million into the country with just $8 \mathrm{l} / \mathrm{s}$ while the small farmers ... how much foreign currency are they earning?"

\section{Complaints and strategies by Indigenous communities}

Historically, a wide array of social movements in the Andean countries, gathering local organizations and communities and national networks-often now in coordination with international organizations - have fought the monopolization of land and water resources and pollution of water sources (see, e.g., Boelens 2015a; Colloredo-Mansfield 2012; Terhorst et al. 2013; de Vos et al. 2006). Nevertheless, surprisingly few cases of large-scale organized resistance are seen against flower agribusinesses' increased use of water resources, expanding political power, and 'virtual water encroachment'. Here the Tabacundo history is an emblematic case.

Although peasant-Indigenous communities in Tabacundo were culturally and socially broken apart during the prolonged colonial and neo-colonial period, in 2004, they set up a second-tier organization: CODEMIA, ${ }^{16}$ to take over the administration of the Acequia Tabacundo. CODEMIA comprised five grassroots organizations grouping some 49 communities. Customs and traditions historically rooted in peasant-Indigenous identity were essential, such as assisting the general assembly of all water users and the minga work party. Due to their rootedness these customs are highly valued by local Indigenous and mestizo peoples. During the local water struggles, they were strategically used to claim and legitimize local communities access to Acequia Tabacundo's waters. As the president of CODEMIA stated:

"Water rights have to be gained... one has to participate in mingas (collective work) participate in meetings [...] participate in the community as water user and community member. One has to fulfill the obligations, like pay the water fee and contribute with labour. One loses his water right if one does not fulfill his obligations".

In 2006, after years of injustice from inequitable access to irrigation water, nearly 3,000 peasant-mestizo and Indigenous people forcibly took over the infrastructure of the Acequia Tabacundo (Chontasi 1987; Hidalgo 2010; Poats et al. 2007; Cf. Hoogesteger 2012; Hoogesteger and Verzij1 2015). They based their claims to water rights on the fact that the canal had been constructed by their ancestors in the early 20th century and on the fact that the water originates in their territories. As mentioned by a 70-year-old aguatero:

"This old canal has been constructed by our ancestors, therefore we have the right to its waters!"

This legitimized their three-day action. They broke the padlocks off canal gates, administered up to then by the Municipality of Pedro Moncayo, and put on their own locks.

${ }^{16}$ Consortium of Development for Integrated Water and Environmental Management of Cayambe-Pedro Moncayo. 
All users had to take part in this action. Later their participation would be taken into account when re-obtaining their right to water. The President of CODEMIA mentioned: "This event claimed and reconstructed rights".

As the communities depend heavily on the large flower companies for their income, the Indigenous organization did not withdraw the companies' water entitlements, but this conquest brought about major water security changes. First, the big companies were forced to take less canal water, and invest in reservoirs to collect rainwater from their greenhouses' rooftops. During the last decade the water saved is increasingly used by Indigenous smallholders and their communities, particularly located at the tail-end, for subsistence agriculture, but also to irrigate their own micro rose farms. Water turns were distributed in a more equitable manner. Next, representatives of the flower companies have to attend communal assemblies of local water users and contribute labor to collective acequiarelated activities (mingas), reinforcing and hybridizing local mestizo-Indigenous traditions. As a distressed large flower-grower mentioned:

"When the irrigation system was managed by the municipality we only paid for the irrigation service, we had nothing to do with the management of the system. Now (with the irrigation system being managed by CODEMIA), apart from fee payment, we have to collaborate with labourers for the Indigenous mingas and the assemblies. Before, the municipality had personnel to do the maintenance work. Now, we have to assist at many meetings...we are busy, we do not have time to go to faraway meetings. With the municipality the situation was better; irrigation was just a service we paid for!"

Though this is not a major monetary sacrifice for flower farms, the symbolic implication of this submission to Indigenous costums and rules is an important rupture from the big landowner's dominance inherited from the hacienda era (Mena-Vásconez et al. 2016). Boelens and Gelles (2005) provide similar cases in Peruvian and Ecuadorian contexts: after expropriation and standardization of Indigenous water management rules, rights and rituals under colonial, nation-State and neoliberal orders, today many of these same water institutions are being reappropriated and redirected by local communities under new, strategic forms of Indigenous practice and discourse.

Interestingly, these Acequia Tabacundo struggles to shape more equitable water access and decision-making make clear how historical Indigenous traditions, symbols, and identities, such as mingas, rotative leadership structures, Indigenous decision-making customs, but also water rituals and Indigenous banners as the means of struggle, far beyond static patterns and structures, are creatively re-worked and deployed. While during and after the agrarian reform periods the Tabacundo communities tended to identify as campesino (peasant) communities, engaged in the class struggles of that time, they strategically affiliated and identified with the rising Indigenous movement of the 1990s. Adopting and adapting pan-Andean Indigenous symbols and principles, they were able to locally mobilize thousands of families while nationally allying with strong support from the Indigenous movement.

Indigenous communities' effective force to mobilize against extractive industry and social injustice was grounded in hybrid forms of organization. These identity-based organizational forms were informed by the relatively recent political cooperativism-for example, encouraged by the State as a prerequisite to access land during agrarian reform in the 1960s - and by cultural grassroots organizations that have managed their own natural resources and means of production for centuries, since before even the Spanish conquest. So, CODEMIA's claim was political, and rooted in a hybrid/ancestral territory and identity 
that transcends local boundaries. CODEMIA's principles match those of political organizations demanding political recognition for Indigenous peoples and nationalities nationwide, such as CONAIE (Confederation of Indigenous Nationalities of Ecuador) and their political party, Pachakutik. They arose from struggles and resistance against neoliberalism in the 1990s. This synergy between local and national battles has made CODEMIA the forum for major protests against water policies and laws that undermine peasant-Indigenous communities' autonomy and identity. This has also enabled CODEMIA to use this same historical-identity-based legitimacy to demand the right to administer the new Cayambe-Pedro Moncayo irrigation canal being built by the Decentralized Autonomous Government of Pichincha province and the national government.

\section{Conclusions}

Throughout Latin America, globalization and intensification of world trade has driven rapid monopolization of land and water, depletion of water flows and aquifers, and growing pollution of water resources. The Andean region is an exemplary case; transnational companies' extraction practices through mining and agro-exports commonly drain local communities' water in order to export commodities, producing new political geographies. They re-pattern mostly Indigenous hydrosocial territories, while making great profits abroad. Re-creating the pishtaku ghoul on a vast scale, these companies suck away Indigenous people's fundamental livelihoods. This increasing competition for water among different uses and users with profoundly unequal power bases, is a hotbed for conflicts, which are increasing in number and harshness. Therefore, water rights and access have become a pivotal issue in local communities' defense of their livelihoods and future security.

This defense is extremely complicated. Mining and agro-industrial companies-including capitalist flower companies-have almost hegemonic discursive and operational power, not only because of their great economic power, but also because of the backing they receive from the State and their legal and military-police defenders.

Notwithstanding official discourse in most Andean countries, promoting integrated water resource management in the name of equity, democracy, and sustainability, State legislation and policy has favored the most powerful users' interests (agro-exporters, cities, mines, logging and hydropower companies) and interfered with local management of community water resources. Indeed, water legislation poorly matches the practical realities of local water management. This effectively discriminates against local normative frameworks but is justified by considering those systems 'backward', needing urgently to be modernized.

So, Andean governments and elites have often undermined peasant-Indigenous societies' subsistence means and strategies, using diverse economic and cultural-political modalities and strategies to marginalize local rights, effectively denying that multiple cultures and identities can coexist, and oppressing local peoples' management and selfdetermination. The northern Ecuador Acequia Tabacundo illustration is a case in point. The drive to modernize agrarian structure with large commercial flower export companies and transnational agribusiness chain development is part of the neoliberal utopian 'plan for salvation'. Rose production, however, concentrates most available irrigation water (quantity and security) for agribusinesses to the detriment of traditional food crops. Flower-export companies can pay more for access to water and infrastructure maintenance, 
a perverse incentive that has prompted inequitable water allocation practices. Growing use of water for flower export agriculture in the Tabacundo area has deeply affected local ecosystems and Indigenous communities' socio-cultural fabric.

The Tabacundo case, a new episode in the lengthy Andean history of Indigenous subjugation and exploitation, shows local water security again increasingly threatened by water capture, now 'virtual' water flows-yet very real and material-in a context dominated by agro-export companies. They control water via material-technological forces that alter water flows, economic power, influence on national policies, and prerogatives to set internationally enforced production standards, as well as local people's need to sell their labor.

We also have shown, however, how along with broader national and international Indigenous mobilization during the last two decades, 'water' in Ecuador and the Tabacundo case has become a prominent issue in social protests against economic marginalization, ethnic discrimination, and undemocratic governance. To counteract encroachment on their livelihoods, territories, and water sources, and to defend themselves against the ways in which their rightful protests are being criminalized by dominant discourse and 'national security laws', Indigenous communities engage in legislative and everyday onthe-ground struggles. In Tabacundo, these water rights arenas seldom have open conflicts. Rather, continued application and creative proliferation of 'Indigenous water rights frameworks' in everyday water control is a powerful way to contest dominant power structures and foster Indigenous claims to water resources and legitimacy. These struggles challenge encroachment on Indigenous users' collective water rights, going beyond 'resource struggles'. Indigenous peoples demand recognition of territorial rights, fair water distribution, and legitimization of local authorities and normative frameworks. In other words, as the Tabacundo communities have shown, Indigenous water user collectives engage in political-strategic action to defend water access rights, define water control rights, legitimize local authority, and confront powerful discourses. Here, Indigenous water rights and identities reveal long-standing trajectories and strong historical roots while simultaneously being quite flexible and adaptive, deployed as dynamic and hybrid arms in a struggle for recognition of diversity, co-decision in governance practice, and redistributive social justice.

Open Access This article is distributed under the terms of the Creative Commons Attribution 4.0 International License (http://creativecommons.org/licenses/by/4.0/), which permits unrestricted use, distribution, and reproduction in any medium, provided you give appropriate credit to the original author(s) and the source, provide a link to the Creative Commons license, and indicate if changes were made.

\section{References}

Achterhuis H, Boelens R, Zwarteveen M (2010) Water property relations and modern policy regimes: neoliberal utopia and the disempowerment of collective action. In: Boelens R, Getches D, Guevara-Gil A (eds) Out of the mainstream. Water rights, politics and identity. Earthscan, London, pp 27-55

Allan JA (2003) Virtual water: the water, food, and trade nexus. Useful concept or misleading metaphor? Water Int 28(1):106-113

Ansión J (ed) (1989) Pishtacos: de verdugos a sacaojos. Tarea, Lima

Arguedas JM (1964) Todas las sangres. Editorial Milla Batres, Lima

Babidge S (2015) Contested value and an ethics of resources: water, mining and indigenous people in the Atacama Desert, Chile. Aust J Anthropol 27(1):84-103

Baud M, De Castro F, Hogenboom B (2011) Environmental governance in Latin America: towards an integrative research agenda. ERLACS 90:78-88 
Bauer C (1998) Slippery property rights: multiple water uses and the neoliberal model in Chile, 1981-1995. Nat Resour J 38(1):109-155

Bauer C (2005) In the image of the market: the Chilean model of water resources management. Int J Water $3(2): 146-165$

Bebbington A (2009) Latin America: contesting extraction, producing geographies. Singap J Trop Geogr 30:7-12

Bebbington A, Humphreys-Bebbington D, Bury J (2010) Federating and defending: water, territory and extraction in the andes. In: Boelens R, Getches DH, Guevara-Gil JA (eds) Out of the mainstream: water rights, politics and identity. Earthscan, London, pp 307-328

Becker M, Tutillo S (2009) Historia Agraria y Social de Cayambe. Abya Yala, Quito

Berry KA, Mollard E (2010) Social participation in water management and governance: critical and global perspectives. Earthscan, London

Boelens R (2015a) Water, power and identity. The cultural politics of water in the Andes. Earthscan, Routledge, London, Washington DC

Boelens R (2015b) Water justice in Latin America. The politics of difference, equality, and indifference. CEDLA and University of Amsterdam, Amsterdam

Boelens R, Gelles PH (2005) Cultural politics, communal resistance and identity in Andean irrigation development. Bull Latin Am Res 24(3):311-327. doi:10.1111/j.0261-3050.2005.00137.x

Boelens R, Seemann M (2014) Forced engagements. Water security and local rights formalization in Yanque, Colca Valley, Peru. Hum Organ 73(1):1-12. doi:10.17730/humo.73.1.d44776822845k515

Boelens R, Vos J (2012) The danger of naturalizing water policy concepts. Water productivity and efficiency discourses from field irrigation to virtual water trade. J Agric Water Manag 108:16-26

Boelens R, Vos J (2014) Legal pluralism, hydraulic property creation and sustainability: the materialized nature of water rights in user-managed systems. COSUST 11:55-62. doi:10.1016/j.cosust.2014.10.001

Boelens R, Guevara-Gil A, Panfichi A (2009) Indigenous water rights in the Andes: struggles over resources and legitimacy. J Water Law 20(5-6):268-277

Boelens R, Hoogesteger J, Baud M (2015) Water reform governmentality in Ecuador: neoliberalism, centralization and the restraining of polycentric authority and community rule-making. Geoforum 64:281-291. doi:10.1016/j.geoforum.2013.07.005

Budds J (2010) Water rights, mining and indigenous groups in Chile's Atacama. In: Boelens R, Getches D, Guevara A (eds) Out of the mainstream. Water rights, politics and identity. Earthscan, London, pp 197-211

Budds J, Hinojosa L (2012) Las industrias extractivas y los paisajes hídricos en transición en los países andinos. In: Isch E, Boelens R, Peña F (eds) Agua, Injusticia y Conflictos. CBC, Cusco, pp 45-62

Buitrón A, y Salisbury BB (1947) Condiciones de vida y trabajo del campesino de la provincia de Pichincha. Instituto Nacional de Previsión, Quito

Chontasi L (1987) El acceso al riego en Tabacundo. Ecuador Debate 14:131-141

Colloredo-Mansfield R (2012) Fighting like a community: Andean civil society in an era of Indian uprisings. University of Chicago Press, London

Cremers L, Ooijevaar M, Boelens R (2005) Institutional reform in the Andean irrigation sector: enabling public water agencies for strengthening local rights and water management. Nat Resour Forum 29:37-50. doi:10.1111/j.1477-8947.2005.00111.x

de Vos H, Boelens R, Bustamante R (2006) Formal law and local water control in the Andean Region: a Fiercely Contested Field. Int J Water Resour Dev 22(1):37-48. doi:10.1080/07900620500405049

Duarte-Abadía B, Boelens R (2016) Disputes over territorial boundaries and diverging valuation languages: the Santurban hydrosocial highlands territory in Colombia. Water Int 41(1):15-36. doi:10.1080/ 02508060.2016.1117271

Duarte-Abadía B, Boelens R, Roa-Avendaño T (2015) Hydropower, encroachment and the repatterning of hydrosocial territory. The case of Hidrosogamoso in Colombia. Hum Organ 74(3):243-254. doi:10. $17730 / 0018-7259-74.3 .243$

Finn M, Jackson S (2011) Protecting indigenous values in water management: a challenge to conventional environmental flow assessments. Ecosystems 14:1232-1248

Gaybor A (2011) Acumulación en el campo y despojo del agua en el Ecuador. In: Boelens R, Cremers L, Zwarteveen M (eds) Justicia Hídrica. IEP, Lima, pp 195-208

Gelles P (2010) Cultural identity and indigenous water rights in the Andean Highlands. In: Boelens R, Getches DH, Guevara Gil JA (eds) Out of the mainstream: water rights, politics and identity. Earthscan, London, pp 119-144

Guamán-Poma de Ayala F (1992 (1615)) El Primer Nueva Corónica y Buen Gobierno. Siglo XXI Editores, Mexico City 
Guevara-Gil A, Boelens R, Getches DH (2010) Conclusions. Water rights, power and identity. In: Boelens R, Getches D, Guevara-Gil A (eds) Out of the mainstream. Earthscan, London, pp 329-340

Harris L, Roa-García MC (2013) Recent waves of water governance: constitutional reform and resistance to neoliberalization in Latin America (1990-2012). Geoforum 50:20-30

Hendriks J (2010) Water laws, collective rights and system diversity in the Andean Countries. In: Boelens R, Getches D, Guevara-Gil A (eds) Out of the mainstream. Water rights, politics and identity. Earthscan, London, pp 165-182

Hidalgo JP (2010) Dinámica de Acumulación de Derechos de Agua y Conflictos. Estudio de caso de la Acequia Tabacundo, Ecuador, Research Report, Wageningen University, Wageningen

Hidalgo JP (2016) La floricultura y la exclusión de acceso al agua de riego: El caso de la acequia Tabacundo en la Sierra ecuatoriana. In: J Budds, C Roa-García (eds) Justicia Hídrica. PUCP, Lima (in press)

Hidalgo F, Lacroix P, Román P (2013) Comercialización y soberanía alimentaria. SIPAE, Quito

Hogenboom B (2012) Depoliticized and repolitiziced minerals in Latin America. J Dev Soc 28(2):133-158

Hoogesteger J (2012) Transforming social capital around water: water user organizations, water rights, and nongovernmental organizations in Cangahua, the Ecuadorian Andes. Soc Nat Resour 26:60-74

Hoogesteger J, Verzijl A (2015) Grassroots scalar politics: insights from peasant water struggles in the Ecuadorian and Peruvian Andes. Geoforum 62:13-23

Hoogesteger J, Boelens R, Baud M (2016) Territorial pluralism: water users' multi-scalar struggles against state ordering in Ecuador's highlands. Water Int 41(1):91-106. doi:10.1080/02508060.2016.1130910

Jackson S, Palmer L (2015) Reconceptualising ecosystems services: possibilities for cultivating and valuing the ethics and practices of care. Prog Hum Geogr 39(2):122-145

Korvkin T, San Miguel-Valderrama O (2007) Labour standards, global markets and non-state initiatives: colombia's and Ecuador's flower industries in comparative perspective. Third World Q 28(1):117-135

Lynch BD (2012) Vulnerabilities, competition and rights in a context of climate change toward equitable water governance in Peru's Rio Santa Valley. Glob Environ Change 22(2):364-373

Mena-Vásconez P, Boelens R, Vos J (2016) Food or flowers? Contested transformations of community food security and water use priorities under new legal and market regimes in Ecuador's highlands. J Rural Stud 44:227-238

Perreault T (2014) What kind of governance for what kind of equity? Towards a theorization of justice in water governance. Water Int 39(2):233-245

Poats S, Zapatta A, Cachipuendo C (2007) La acequia Tabacundo y las microcuencas de los ríos Pisque y la Chimba. In: Derechos de Agua y Gestión Ciudadana. Agua Sustentable, Quito

Portocarrero G (1991) Sacaojos: Crisis social y fantasmas coloniales. Tarea, Lima

Prieto M (2015) Privatizing water in the Chilean Andes: the case of Las Vegas de Chiu-Chiu. Mt Res Dev 35(3):220-229

PROECUADOR (2013) Análisis sectorial de flores. Dirección de inteligencia y comercial, Quito

Rehner J, Beaza SA, Barton JR (2014) Chile's resource-based export boom and its outcomes: regional specialization, export stability and economic growth. Geoforum 56:35-45

Roa-García MC (2014) Equity, efficiency and sustainability in water allocation in the Andes: trade-offs in a full world. Water Altern 7(2):298-319

Rodriguez de Francisco JC, Budds J, Boelens R (2013) Payment for environmental services and unequal resource control in Pimampiro, Ecuador. Soc Nat Resour 26:1217-1233. doi:10.1080/08941920.2013. 825037

Romano S (2012) From protest to proposal: the contentious politics of the Nicaraguan anti-water privatisation social movement. Bull Latin Am Res 31(4):499-514

Rubio B (2008) El dominio del capital en actividades no tradicionales de exportación: las florícolas. In: Rubio B, Campana y F, Larrea F (eds) Formas de explotación y condiciones de reproducción de las economías campesinas en el Ecuador. HEIFER, Quito, pp 35-60

Saldías C, Boelens R, Wegerich K, Speelman S (2012) Losing the watershed focus: a look at complex community-managed irrigation systems in Bolivia. Water Int 37(7):744-759. doi:10.1080/02508060. 2012.733675

Sawers L (2005) Non-traditional or new traditional exports: ecuador's flower boom. Latin Am Res Rev 40(3):40-67

Schlosberg D (2004) Reconceiving environmental justice: global movements and political theories. Environ Polit 13(3):517-540

Seemann M (2016) Inclusive recognition politics and the struggle over hydrosocial territories in two Bolivian highland communities. Water Int 41(1):157-172

Soper R (2013) Reclaiming development: indigenous community organizations and the flower export industry in the Ecuadorian Highlands. In: Becker M (ed) Indigenous and Afro-Ecuadorians facing the twenty-first century. Cambridge Scholars, Newcastle, pp 128-149 
Starn O (1994) Rethinking the politics of anthropology. The case of the Andes. Curr Anthropol 35(1):13-38

Stoltenborg D, Boelens R (2016) Disputes over land and water rights in gold mining: the case of Cerro de San Pedro, Mexico. Water Int 41(3):447-467. doi:10.1080/02508060.2016.1143202

Terhorst P, Olivera M, Dwinell A (2013) Social movements, left governments and the limits of water sector reform in Lain America's left turn. Latin Am Perspect 40(4):55-69

von Benda-Beckmann F (1981) Forum shopping and shopping forums. J Legal Plur 19:117-159

Vos J (ed) (2010) Riego campesino en los Andes. Seguridad hídrica y seguridad alimentaria en Ecuador, Perú y Bolivia. IEP, Lima

Vos J, Boelens R (2014) Sustainability standards and the water question. Dev Change 45(2):205-230. doi:10.1111/dech.12083

Vos J, Hinojosa L (2016) Virtual water trade and the contestation of hydrosocial territories. Water Int 41(1):37-53. doi:10.1080/02508060.2016.1107682

Yacoub C, Duarte-Abadía B, Boelens R (2015) Agua y Ecología Política. El extractivismo en la agroexportación, la minería y las hidroeléctricas en Latino América. Abya-Yala, Quito

Zapatta Á, Mena-Vásconez P (2013) Acumulación de agua y floricultura en un mosaico de territorios de riego: el caso Pisque, Ecuador. In: Boelens R, Arroyo A (eds) Aguas Robadas: despojo hídrico y movilización social. AbyaYala, Quito

Zimmerer KS (2000) Rescaling irrigation in Latin America: the cultural images and political ecology of water resources. Ecumene 7(2):150-175

Zoomers A (2010) Land, water and the search for sustainable livelihood in the Andes. In: Boelens R, Getches D, Guevara-Gil A (eds) Out of the mainstream. Water rights, politics and identity. Earthscan, London, pp 145-163

Zwarteveen M, Boelens R (2014) Defining, researching and struggling for water justice: some conceptual building blocks for research and action. Water Int 39(2):143-158. doi:10.1080/02508060.2014.891168

Juan Pablo Hidalgo is an agricultural engineer and holds a Masters of Science degree in International Land and Water Management. He currently is a PhD candidate at the Centre for Latin American Research and Documentation (CEDLA) and the Department of Geography, Planning, and International Development Studies of the University of Amsterdam. His dissertation focuses on the political ecology of water, particularly on the power relations embedded in multipurpose mega-hydraulic projects in coastal Ecuador. He worked several years as policymaker for the Ecuadorian government and he is a member of the International Water Justice Alliance (www.justiciahidrica.org) and the Ecuadorian National Water Forum.

Rutgerd Boelens is Professor of Water Governance and Social Justice at Wageningen University, the Netherlands, and Professor of Political Ecology of Water in Latin America with CEDLA, University of Amsterdam. He also is a Visiting Professor at the Catholic University of Peru and the Central University of Ecuador, and he directs the International Water Justice alliance. Among his recent books are: "Water, Power and Identity. The Cultural Politics of Water in the Andes" (Routledge, 2015); "Out of the Mainstream: Water Rights, Politics and Identity" (with D. Getches \& A. Guevara, Earthscan, 2010/2012). Forthcoming: "Water Justice" (with T. Perreault \& J. Vos, Cambridge University Press, 2017).

Jeroen Vos is an Assistant Professor with the Department of Environmental Sciences at Wageningen University, the Netherlands. As a water policy advisor he worked a decade in Peru and Bolivia with different international development organizations. He was editor of two Spanish language books on water management in Latin America. His current research interests are the dynamics and discourses of water use by agribusinesses in Latin America. He has published several articles on the effects of virtual water trade and water stewardship certification. 